\title{
Knowledge Management: an Analysis From the Organizational Development
}

\author{
Rodrigo Valio Dominguez Gonzalez', Manoel Fernando Martins²
}

\begin{abstract}
This research develops a theoretical framework on the implications of the organizational characteristics on the knowledge management (KM). The organizational characteristics are handled in this work as constructs, as they are complex concepts. This paper is based on a theoretical research, considering original and classic articles on KM. From a broad theoreticalconceptual research, the paper presents as a result five organizational constructs that support the KM process: human resources, team work, organizational culture, organizational structure and development and absorption of knowledge. The article presents the implications of these constructs in relation to the four phases of the KM process (acquisition, storage, distribution and use of knowledge).
\end{abstract}

Keywords: Knowledge Management; Human Resources; Teamwork; Organizational Culture; Organizational Structure.

'School of Applied Science, University of Campinas, Rua Pedro Zaccaria, I300, I3484-350, Limeira - SP, Brazil. Rua Pedro Zaccaria, I 300. Limeira - SP. CEP 13484-350. Phone: +55 19 370I 6683, Fax: ++55 19 3701 6680. e-mail: rodrigo.gonzalez@fca.unicamp.br 2Production Engineering Department, Federal University of São Carlos, Rodovia Washington Luis, Km 235, I3565-905, São Carlos-SP, Brazil. e-mail: manoel@ufscar.br 


\section{Introduction}

As knowledge is recognized as the primary organizational resource of the 21 st century, which is able to bring sustainable competitive advantage in the long term, several studies have focused on knowledge management (KM). Authors such as Davenport et al. (1998) showed, at the end of the 20th century, that several organizations around the world introduced initiatives for the KM based, typically, on information technology (IT), which promotes a broad dissemination and access to knowledge by individuals in the organization. However, the focus of several studies dealing with KM has moved to the study of organizational aspects, emphasizing the role of employee development (Gonzalez and Martins, 2014; Quigley et al., 2007; Cross and Sproull, 2004), an organizational culture that fosters knowledge sharing (Davenport and Prasak, 1998; Terziovski, 2003) and an organizational structure that allows the integration of employees and departments of an organization (Andrews and Kacmar, 200I; Pandey and Duta, 2013;Wilkinson and Young, 2006).

Such guidance is due to the fact that IT has become effective in the process of storage and sharing of data and information. Knowledge, however, should not be confused with information, as knowledge is more complex than information (Davenport; Prusak, 1998). Knowledge depends on the human action and results from the interaction of insights, judgment and intuition about information, being influenced by the personality, imagination and experience of its holder (Lee and Yang, 2000).

Considering that knowledge is in the tacit and explicit form (Nelson and Winter, 1982), the KM process becomes more complex than the use of IT. The explicit or codified portion of the knowledge can be stored in repositories and use IT as a tool to support storage and dissemination. Tacit knowledge, in turn, depends on an organizational architecture, including organizational structure and culture, which stimulates the interaction and cooperation between individuals (Lytras and Pouloudi, 2006). In this context, this article aims to analyze the organizational characteristics that enable organizations to effectively manage their knowledge, resulting in a sustainable competitive advantage.

Several authors such as Grant (1996) and Davenport and Prusak (1998) emphasize the role of knowledge as an organizational asset capable of generating competitive advantage. Other authors such as Walsh and Ungson (1991), Rowley (200I), Zheng et al. (20I0) and Liao et al. (20I I) propose models for KM based on phases: creation, storage, distribution and utilization of knowledge. However, there is a gap in the theory on KM about the factors or constructs that support the KM process in organizations. In this sense, this research aims to develop a theoretical framework that answers the following question: Which internal contextual aspects should be developed to organization promotes the KM process? Since these constructs are mapped, another question that arises is: How each of these constructs relate to the stages of the KM process (acquisition, storage, distribution and knowledge utilization)?

In order to answer these two questions, this article is structured, in addition to this introduction, four other sections. The next section deals with the KM process, defining and bringing to light the issues that drive the organizational constructs that support KM. The third section explores five organizational constructs conceptually related to the KM process, human resource development, teamwork, organizational culture, organizational structure and knowledge development and absorption in order to answer the first research question. Next, the article assesses the implications of the five mapped constructs to four phases of the $\mathrm{KM}$ process, answering the second research question. Finally, the last section presents concluding remarks on the mapped constructs.

\section{Knowledge management as a process}

It is a known fact that KM is one of the principal means of achieving competitive advantage (Grant, 1996). All organizations need to process knowledge in order to promote their strategy, and KM is the process responsible for such processing. From a review of the literature, we can notice that there are different approaches to KM process (Table I).

These different visions denote the diversity of subjects surrounding the KM. Two main characteristics can be observed from these approaches. The first addresses the KM as a subject restricted to the IT scope. One of the main problems about the contribution of the IT on the KM is the difficult and/or impossibility to register the tacit knowledge of individuals, because it is impossible to absorb or scan the contents of the human mind and store it in a database (Bhatt, 2002). Other approaches, in turn, are based on organizational development, with regard to the organizational structure and culture to facilitate and enhance the interaction between individuals, fostering knowledge sharing (Rowley, 200I).

KM should combine IT with the organizational development, including the organizational culture and structure, being an activity that develops, stores and transfers knowledge, aiming to provide the necessary information so that the organization members take the right decisions (Gonzalez and Martins, 20I4;Alavi and Leidner, 200I).

Thus, this article has the main interest the analyses of the development of organizational characteristics, called 'soft', 


\begin{tabular}{ll}
\hline \multicolumn{1}{c}{ Author } & \multicolumn{1}{c}{ Approaches } \\
\hline Poynder & - KM is a restricted topic to IT, and networks of computers and GroupWare are the cen- \\
$(1998)$ & tral subjects;
\end{tabular}

- KM is a subject related to the human resources with an emphasis on the organizational culture and the formation of team works;

- KM depends on the development of organizational processes that make it possible to measure and capture the know-how of the organization.

Swan et al. - It-based model that focus on the processing and intense dissemination of information.

(1999) This model is intended for the exploitation of knowledge, using technical means;

- Community-based models, which emphasize dialogue and collaboration within a network; The goal of this model is the exploration of knowledge, focused mainly on the interaction between individuals.

Alvesson and Kärreman

(2001)

Lee and Kim

(2001)

Schultze and Leidner (2002)
The KM models are established from the combination of two elements: the means of interaction (social and technostructure) and managerial intervention mode (coordination and control). From these two guidelines, the authors have defined four models for KM:

- Community-based, originated from the social interaction and coordination management intervention. Emphasis on the sharing of ideas;

- Based on normative control, originated from the social interaction and control management intervention. Emphasis on the normative control. The organizational culture acts as a knowledge repository;

- Based on stored experiences, originated from the interaction based on technostructure and coordination management intervention. Emphasis on the formation of a 'knowledge library'.

- Based on rules and modes of action, originated from the interaction based on technostructure and control management intervention. Emphasis on the development of templates that describe specific modes of action.

- Managerial model: it has as central element the development of the 'knowledge worker', including leadership, autonomy, performance measurement and rewards, organizational structure and organizational culture;

-Technical model: it has as central element the IT. This perspective emphasizes the facilitation of the process of storage and distribution of knowledge by means of knowledge management systems, including data mining, discussion forums, Internet and intranet.

- Objective model: knowledge seen as an object to be discovered. Knowledge is identified in a variety of ways and locations, and the technology has a leading role in the coding of this way of knowledge.

- Subjective model: knowledge is inherently identified and related to the human experience through the social practice of knowledge, as seen in the work of community of practice (Brown and Duguid, 2001; Wenger, 1998 and Thompson, 2005). 
which support the KM process, positioning the tools, called 'hard', as support mechanisms for this process. In relation to the KM process, it can be defined as the management effort to promote and facilitate the activities of acquisition, storage, distribution and utilization of knowledge by individuals and groups (Gonzalez and Martins, 2014; Cormican and O'Sullivan, 2003; Zheng et al., 20 I0; Liao et al., 20I I).

The acquisition relates to the intra-organizational process that facilitates the creation of tacit and explicit knowledge, from the individuals and integrating at the organizational level, as well as the identification and the absorption of information and knowledge from external sources (Gold et al., $200 \mathrm{I}$ ). The acquisition process is also related to the organizational stimulus to learning of employees, which makes the company able to integrate, build, and reconfigure its internal competences to respond to environmental changes (Teece, 2007; Cohen and Levinthal, 1990), promoted through the development of a culture focused on learning (Skerlevaj et al., 2007; Irani et al., 2009).

The stage of knowledge storage refers to the process of organizational memory formation (Walsh and Ungson, 1991), in which knowledge is formally stored in physical memory systems, informally retained as values, standards and beliefs that are associated with the organizational structure and culture (Alavi and Leidner, 200I), and also retained in the organizational processes, tools and routines (Kane and Alavi, 2007).

The knowledge distribution refers to the process by which new information from different sources is shared and which eventually can drive the creation of new knowledge (Lee and Yang, 2000). The earlier works about the knowledge transfer process emphasized cognitive and social factors. Currently, the focus is on organizational factors that facilitate or inhibit the transfer process, including the absorptive capacity of the organization (Cohen and Levinthal, 1990), the development of a sharing culture (Skerlavaj et al., 2007), expertise developed by individuals (Cross and Sproull, 2004), motivational aspects (Amayah, 2013; Quigley et al., 2007) and technology that eases the transfer process (Kane and Alavi, 2007).

Regarding the knowledge utilization phase, Rowley (200I) defines it as the ability of the individuals of an organization locate, access and use information and stored knowledge in the formal and informal memory systems of the organization. The use can take on an exploiting character, when, through the existing knowledge base, decisions or improvements are made; or an exploratory character, when the primary organizational knowledge is used as a base for the creation of new knowledge in an innovative proposal (Cohen and Levinthal, 1990; Rowley, 200 I).
These stages indicate that the KM process is more complex than information management and IT plays a supporting role mainly in the processes of retention and distribution of explicit knowledge. The processes of acquisition and use of knowledge requires the development of an organizational context that facilitates the search for new ways of doing things, stimulating exploitative and explorative learning, i.e. the refinement and improvement of processes from the same primary knowledge base, and innovation and improvement of processes from a technological paradigm shift and change of primary knowledge base, respectively. Thus it is possible to see that the KM process is based on development of human resources. It is from the human knowledge is created and put into practice. Without qualified employees no process $\mathrm{KM}$.

The stages of storage and distribution with respect to the portion of the explicit knowledge are supported and expanded by the IT tools. Tacit knowledge is retained by culture, in relation to behavior, beliefs and way of doing the things, and also through the organizational structure with respect to the degree of formalization, allocation and hierarchy (Irani et al., 2009; Liao et al., 20II; Pandey and Duta, 2013) The organizational structure can be considered a key organizational feature for the KM process, because it is responsible for enabling the flow of knowledge between individuals and organizational departments, and also to create mechanisms for the integration of individuals (Chen et al.,2010).

Organizational culture also influences the knowledge distribution process, especially tacit knowledge. The culture of knowledge, a term used by authors such as Irani et al. (2009), Skerlavaj et al., 2007; Terziovski et al., 2003, is focused on cooperation and knowledge exchange between individuals.

Teamwork is another aspect developed by organizations which promotes the integration of individuals and exchange of tacit knowledge. Through teamwork, less experienced employees have contact with a body of knowledge hitherto dominated by more experienced employees. Teamwork is also important for $\mathrm{KM}$ because it facilitates the integration of multi-disciplinary knowledge, facilitating the knowledge acquisition and utilization.

Since organizational knowledge is disseminated, individuals begin to use knowledge in exploitative or explorative learning approaches. Thus, the organization develops new knowledge through the knowledge transformation cycle promoted learning process. Besides the development of external knowledge, the primary knowledge base is essential to promote the absorption of external knowledge. 
The next section discusses theoretically the content of these five constructs (human resource development, teamwork, organizational culture, organizational structure and knowledge development and absorption) as well as their relation with the four stages of the KM (knowledge acquisition, storage, distribution and utilization).

\section{Organizational constructs related to knowledge management process}

This section aims to determine the organizational constructs that promote each stage in the KM process, answering the following research question: Which internal contextual constructs should be developed to organization promotes the KM process? Constructs can be defined as the set of concepts that define the object searched; therefore, in this work, we raise the constructs, or set of concepts, from the organizational point of view that support the KM.

Many organizations face the obstacle arising from the "heritage" of the Taylorist approach of production in relation to the development of new knowledge as well as its subsequent distribution and use by the members. Such a model, based on the exclusion of employees of lower hierarchical level from the decision-making process, faces the most modern management proposals, which base their values and in group work and problem-solving, large involvement and training of workers, as well as shared identity and objectives by these groups. Thus, the development of human resources (HRs) is the first construct dealt with in this work.

The view 'organization as a machine' (Morgan, 1996) becomes increasingly outdated when it is aimed to study a form of management that provides the constant acquisition and distribution of knowledge (Rowley, 200I). The KM depends on a social context based on teamwork - groups that share ideas and professional skills (Brown; Duguid, 1991; Orlikowski, 2002) - which promotes the continuous learning of individuals. Therefore, the second construct associated with the organizational context that relates to the KM process is 'Team work'.

Lytras and Pouloudi (2006) address KM as a phenomenon of technical and social order and present a model that integrates the three players involved in KM: persons, covering their experiences, skills, knowledge, cognition and learning ability; the groups, which use the synergy between individuals in order to achieve goals; and the organization, that guides the action of individuals and groups through the structure and culture established. Such integration is achieved from a dynamic flow of knowledge transformation.

Persons, through their experiences, attitudes and knowledge, dictate the behavior of groups. After their formation, the groups go on to develop vision, values, processes, structure and culture over time. Lytras and Pouloudi propose that knowledge undergoes a process of transformation when circulating among individuals, group and organization. The knowledge of each individual is continually changing with the environment due to the group performance. Learning and knowledge flows link persons to groups, as well as these to the organization.

Thus, the 'Organizational Culture' is the third construct highlighted, responsible for the development of similar values and assumptions between individuals, which create an environment conducive to the sharing and integration of knowledge. And the 'Organizational Structure', regarding the degree of autonomy granted to individuals, the division and formalization of work and functional integration, is the fourth construct.

In relation to the development of the organizational knowledge, Nelson and Winter (1982) say that organizations evolve through their learning capabilities. Organizations learn and acquire knowledge through their routines and repositories, taking advantage of the power of cognition and articulation of knowledge by their individuals. Organizations develop, over time, a common knowledge base, which facilitates the absorption of new knowledge, as well as the learning process (Grant, 1996). This way, 'Development and Absorption of knowledge' is the fifth construct related to the organizational context.

The following sections explore the organizational practices related to the five constructs mapped and then we raise the implications of each construct in relation to the KM process.

\section{I Human resources development}

The most modern approaches related to treatment of human resources (HRs) go from premises directed to development of the workforce, in order to constantly improve the skills (Zangiski et al., 2013; Zarifian, 200I; LeonardBarton, 1998).

Research on the HR management suggests that practices related to the development of individuals can increase the performance of the company, facilitating the creation and flow of knowledge capable of generating innovation (Pandey and Duta, 2013; Collins and Clark, 2003).

$K M$ initiatives depend on the willingness of persons to share their knowledge and expertise (Cardoso et al., 2012; Quigley et al., 2007). No organization can generate knowledge without qualified persons (Cross and Sproull, 2004; Zarifian, 200I). And yet, through the HR development practices, organizations can develop an organizational culture that en- 
courages the acquisition and sharing of knowledge (Zangiski et al., 2013). In relation to the transfer of knowledge, the development of HRs is the key element for increasing the absorptive capacity and knowledge utilization (Sparkes and Miyake, 2000). It is important to note that the capacities of individuals built and sustained through $H R$ practices are difficult to imitate, because these practices are specific to a company, socially complex and context-dependent (Collins and Clark, 2003). Table 2 presents the organizational initiatives related to HR development, extracted from six papers on the subject.

Thus, the first organizational initiatives related to the development of human resources that contribute to the KM process are geared to the selection, training and development of employees (Chen and Huang, 2009; López et al, 2006.). The $\mathrm{KM}$ process requires the organization to hire and train individuals with personal characteristics that fit into the company culture, and primary knowledge capable to contribute to the organizational primary knowledge (Cardoso et al., 2012; Vlachos, 2006). The failure in the selection and evaluation of employees with personal characteristics that are adherent to the behaviors and beliefs of the organization can be considered the first step to failure of KM (López et al., 2006).

The lack of appreciation of individual or group initiatives to support the organization's strategy may mean a reduction in process of new knowledge exploration (Lopez et al., 2006). The organization of the performance management system with the awards and recognition systems are important aspects for maintaining and increasing employee motivation (Vlachos, 2008).

The KM is supported from motivated employees to acquire, retain, distribute and use organizational knowledge. For this purpose, the organization must build a participatory internal context in which the employee is motivated to collaborate with a team from their ideas and knowledge (Chen and Huang, 2009). It is critical to KM that the employee is identified with your workgroup without this identification the worker has no motivation to collaborate and disseminate their knowledge (Laursen and Foss, 2003). Organizational
Initiatives

1. Selection process

of employees

2. Training and

Development

3. Performance management system

4. Awards and recognition

5. Involvement and participation

6. Performance of the managers

7. Decentralization

8. Work teams

9. Job rotation
Definition

Organizations require new employees to contribute to the learning and to the knowledge base (Vlachos, 2008; López et al., 2006).

Important mechanisms for the process of knowledge acquisition (Chen and Huang, 2009; López et al., 2006; Vlachos, 2008).

Definition and measurement of the behaviors and skills that can highlight an organization of the competition (Chen and Huang, 2009; Vlachos, 2008)

Denotes the behavioral aspects valued by the organization. Should strengthen an attitude of risk-taking and promote the sharing of knowledge (Cardoso et al., 2012; Laursen and Foss, 2003; López et al., 2006).

Encourages employees to bring new ideas and exchange knowledge about innovative activities (Chen and Huang, 2009; López et al., 2006).

Managers are responsible for two groups of information relevant to innovation. The first concerns external information (customer relations, positioning of competitors, etc.), and the second concerns the selection and grouping of internal information from different groups and different departments (Chen and Huang, 2009; Jiménez-Jiménez and Sanz-Valle, 2007; Lee et al., 2012).

Increased delegation improves the process of discovery and use of knowledge in the organization (Laursen and Foss, 2003; Lee et al., 2012).

Aggregates heterogeneous knowledge of individuals, resulting in non-trivial process improvements or new combinations that result in new products (Laursen and Foss, 2003; Pandey and Duta, 2013; Vlachos, 2008).

Extends the skills group dominated by the employees, making them versatile, intensifying the process of dissemination of knowledge (Laursen and Foss, 2003).

Table 2 - Main initiatives and authors related to the human resources development

ISSN: 07I 8-2724. (http://www.jotmi.org)

Journal of Technology Management \& Innovation (c) Universidad Alberto Hurtado, Facultad de Economía y Negocios. 
initiatives aimed at decentralization, i.e. the exposition of the employees to take decisions on your level of expertise, it is also a strategy that contributes the process of KM. Environments with highly centralized power of decision are not favorable to the acquisition and use of knowledge (Laursen and Foss, 2003).

Organizational strategies that value multidisciplinarity are promoting the processes of knowledge creation, distribution and utilization. Thus, the formation of groups with individuals holding complementary knowledge can be considered an important action for KM process. The practice of job rotation within workgroups is an organizational action in line with the valuation of multidisciplinarity. The job rotation encourages employees to acquire and disseminate knowledge, increasing the variety of individual's competences (Larusen and Foss, 2003).

\subsection{Teamwork}

Teamwork is one of the main characteristics of the most modern forms of work organization, such as lean manufacturing and semi-autonomous groups. London and Sessa (2007), studying the maturity of groups, claim that, in immature groups, individuals maintain distinct points of view, each working on their own, often do not have commitment to the group and learn on their own. In mature or integrated groups, individuals work, learn and make decisions as a single unit. Table 3 presents the organizational initiatives related to team work, extracted from five papers on the subject.

A central aspect for the effectiveness of group work is the knowledge sharing process (Cummings, 2004; Liebowitz et al., 2007; Okhuysen and Eisenhardt, 2002). So that it becomes useful, the individual knowledge, which is the prop- erty of individuals, must be integrated to the groups through a process of assimilation (Crossan et al., 1999) and institutionalized within the organization (Grant, 1996).

However, for the group to become a system, group members need to develop a state of mutual trust, a shared mental model, a shared identity and a cohesion state (Huang, 2009; Lee et al., 2013). Without these characteristics, the groups are collections of individuals (Okhuysen and Eisenhardt, 2002). Without mutual trust, the members of the group spend time and resource with activities of protection, control and inspection. The shared mental model is the convergence of the knowledge structure on the development of tasks that facilitates interpersonal interactions. The identification is the degree in which a group has a clear awareness of its existence, and it also includes cohesion, which is a kind of 'glue' that holds the group together. Cohesion is developed when the members of the group create a sense of commitment to the task, group pride and interpersonal attraction (Huang, 2009; London and Sessa, 2007).

Individuals working in workgroups must hold additional knowledge that can solve problems and continually improve the processes (Liebowitz et al., 2007; London and Sessa, 2007; Schuring, 2006). These two group activities consist of mechanisms that support the continuous acquisition and use of knowledge.

\subsection{Organizational culture}

The existing literature on KM stresses the inseparable relationship between organizational culture and KM (Cardoso et al., 2012; Davenport and Prusak, 2000; Skerlavaj et al., 2007; Terziovski et al., 2003). When an organization adopts a knowledge management system without worrying about the

\begin{tabular}{|c|c|}
\hline Initiatives & Definition \\
\hline $\begin{array}{l}\text { 1. Problem solving and im- } \\
\text { provement activities }\end{array}$ & $\begin{array}{l}\text { Teams are composed of individuals with complementary multidisciplinary skills } \\
\text { that promote the problem solving process (Liebowitz et al., 2007; London and } \\
\text { Sessa, 2007; Schuring, 1996). }\end{array}$ \\
\hline 2. Common language & $\begin{array}{l}\text { The groups are formed by individuals who share a common vocabulary, facilitat- } \\
\text { ing dialogue and intensifying the flow of knowledge (Brown and Duguid, 2001). }\end{array}$ \\
\hline 3. Operational autonomy & $\begin{array}{l}\text { The groups have, especially when considered as mature, autonomy for deci- } \\
\text { sion-making in their scope of operation (London and Sessa, 2007; Schuring, } \\
\text { 1996). }\end{array}$ \\
\hline $\begin{array}{l}\text { 4. Knowledge sharing be- } \\
\text { tween individuals }\end{array}$ & $\begin{array}{l}\text { Employee interaction facilitates the process of dissemination of tacit knowledge } \\
\text { (Cardoso, et al., 2012; Cummings, 2004; Huang, 2009; London and Sessa, 2007). }\end{array}$ \\
\hline $\begin{array}{l}\text { 5. Identity of the employee } \\
\text { against the group }\end{array}$ & $\begin{array}{l}\text { This is about the cohesiveness and reliable state conquered by group members } \\
\text { (Huang, 2009). It is also important the feeling of being part of a team by the indi- } \\
\text { viduals (Brown and Duguid, 2001; London and Sessa, 2007; Huang, 2009) }\end{array}$ \\
\hline
\end{tabular}

Table 3 - Main initiatives and authors related to team work

ISSN: 07 I8-2724. (http://www.jotmi.org)

Journal of Technology Management \& Innovation (c) Universidad Alberto Hurtado, Facultad de Economía y Negocios. 
cultural development that fosters it, the KM efficiency is limited (Zheng et al. 2010). Table 4 presents the organizational initiatives related to the organizational culture, extracted from six papers on the subject.

The survey conducted by Alavi and Leidner (200I) demonstrates that much of the success of the KM initiatives is from a cultural adequacy that encourages employees to share tacit knowledge acquired through experience in routine activities and in the process of problem solving, called culture of knowledge.

The culture of knowledge can be defined as the conditions established by the organization that value the sharing and integration of knowledge between individuals and groups (Cardoso et al., 2012; Fey and Denison, 2003; Irani et al., 2009). In relation to the sharing issue, organizations with more open values, and aimed at the mutual support between individuals, are predisposed to build a knowledge culture (Gold et al., 200I; Fey and Denison, 2003).

The sharing and involvement is also related to the degree of employee identification with the organization (Fey and Denison, 2003; Irani et al, 2009.). When an individual does not feel belonging and accepted within a group, their capacity to contribute becomes limited. Managers, along with the staff, should be capable of creating an aggregator organiza- tional context, i.e., capable of retaining employees, making them motivated to create and share knowledge.

The culture also defines the process of creating and adopting new knowledge (Skerlavaj et al., 2007). The attitude of the organization in the face of failures is an important element of the relationship between culture and the creative process. Irani et al. (2009) point out that failures are inserted into the creative context of organizations and it is up to the management to support employees so that they feel safe and encouraged to create. Thus, managerial action to punish their employees due to attempts that did not generate the expected results generates an organizational context that discourages the creative process and the use of organizational knowledge, i.e., the organization does not encourage the use of their knowledge base (Skerlavaj et al., 2007).

\subsection{Organizational Structure}

Since KM depends on social interactions and on the flow of knowledge between individuals and departments (Zheng et al., 2010), the organizational structure exerts great influence on this process (Chen et al., 2010; Chen and Huang, 2007; Tsai, 2002). According to Lee and Grover (2000), Liao et al. (20II) and Chen and Huang (2007), the organizational structure is defined from three elements, formalization, centralization and integration, related to KM process.

\begin{tabular}{ll}
\hline \multicolumn{1}{c}{ Initiatives } & \multicolumn{1}{c}{ Definition } \\
\hline $\begin{array}{l}\text { 1. Encouraging the sharing of } \\
\text { knowledge }\end{array}$ & $\begin{array}{l}\text { The 'knowledge culture' has as main objective to encourage individuals } \\
\text { to share knowledge, especially tacit knowledge (Alavi and Leidner, 2001; } \\
\text { Davenport and Prusak, 1998; DeLong and Fahey, 2000; Skerlavaj, 2007). }\end{array}$ \\
$\begin{array}{l}\text { 2. Involvement and identifica- } \\
\text { tion of the employee in rela- } \\
\text { tion to the company }\end{array}$ & $\begin{array}{l}\text { Persons of all levels feel responsible for their processes, creating a direct } \\
\text { connection with the goals of the organization (Davenport and Prusak, } \\
1998 ; \text { DeLong and Fahey, 2000; Fey and Denison, 2003, Irani et al., } \\
\text { 2009; Skerlavaj et al., 2007). }\end{array}$ \\
$\begin{array}{l}\text { 3. Participative action of su- } \\
\text { periors }\end{array}$ & $\begin{array}{l}\text { The managers of the organization engage in the process of dissemination } \\
\text { of the knowledge culture (Delong and Fahey, 2000; Fey and Denison, }\end{array}$ \\
2003; Irani et al., 2009; Skerlavaj et al., 2007). \\
4. Posture of risk-taking and \\
stimulus to the creative process
\end{tabular}

Table 4 - Main initiatives and authors related to the organizational culture

ISSN: 07I 8-2724. (http://www.jotmi.org)

Journal of Technology Management \& Innovation (c) Universidad Alberto Hurtado, Facultad de Economía y Negocios. 
Table 5 presents the organizational initiatives related to the organizational structure, extracted from seven papers on the subject.

The formalization refers to the level of coding that guides the behavior of employees. In highly formalized organizations, the existence of formal documents inhibits the generation of ideas and prevents spontaneous behavior necessary to stimulate innovations, while less formalized structures are conducive to innovation (Chen and Huang, 2007; Lee and Grover, 2000; Liao et al., 20I I).

The centralization is related to the direction of the decision-making power to higher hierarchical levels (Andrews and Kacmar, 200I; Ramezan, 20II). The centralization creates a non-participatory environment, reducing communication, commitment and involvement among employees (Damanpour, 1991). In lean organizational structure, employees can determine what actions are most important, thus stimulating innovation and knowledge creation (Liao et al., 20I I;Tsai, 2002).

Integration refers to the degree of interrelationship between individuals and the sectors of the organization (Germain, 1996). The KM requires a heavy flow of communication between members of different sectors of the organization and network structures encourage the sharing of information and knowledge by individuals (Wilkinson and Young, 2006).
Still on the increased flow of information through the organization, it is important to stress the IT role. Organizations depend on IT to store, formalize and distribute the explicit knowledge (Ramezan, 20 I I, Faraj et al., 20I I; Leidner; Elam, 1995). Thus, this work considers IT as a facilitator of the KM process. IT is related in this work with the organizational structure because it provides mechanism that facilitates two key characteristics of the organizational structure: the formalization, providing mechanisms for knowledge retention, and integration regarding tools that facilitate the flow of information and knowledge between individuals and organizational departments.

\subsection{Knowledge development and absorption}

The absorptive capacity refers to the ability of an organization to recognize the value of a given knowledge, assimilate it and apply it, aiming a competitive advantage (Cohen and Levinthal, 1990). The fundamental notion of this concept focuses on the fact that organizations need to access their primary knowledge to assimilate and utilize new knowledge, that is, the accumulation of common knowledge increases the potential for further learning (Cohen; Levinthal, 1990; Holmqvist, 2004).

The contact of organization with new knowledge from the external environment is critical to maintaining and increasing its competitiveness (Teece, 1997), however, when the organi-

\begin{tabular}{|c|c|}
\hline Initiatives & Definition \\
\hline 1. Formalization of activities & $\begin{array}{l}\text { Refers to the degree that the activities of the organization are standardized through } \\
\text { formal documents (Andrews and Kacmar, 2001; Chen and Huang, 2007; Liao et } \\
\text { al., 2011) }\end{array}$ \\
\hline $\begin{array}{l}\text { 2. Intra-organizational } \\
\text { knowledge and information } \\
\text { flow }\end{array}$ & $\begin{array}{l}\text { The knowledge flow between functions (horizontal) and the vertical one (top } \\
\text { down) allows the dissemination of knowledge (Chen and Huang, 2007; Lee et al., } \\
\text { 2012; Lee and Grover, 2000; Leidner and Elam, 1995; Liao et al., 2011; Pandey } \\
\text { and Duta, } 2013 \text { Ramezan, 2011) }\end{array}$ \\
\hline $\begin{array}{l}\text { 3. Lean organizational struc- } \\
\text { ture }\end{array}$ & $\begin{array}{l}\text { It is the decentralization of the decision-making power (Andrews and Kacmar, } \\
\text { 2001; Lee et al., 2012; Ramezan, 2011; Liao et al., 2011; Pandey and Duta, 2013). }\end{array}$ \\
\hline 4. Functional integration & $\begin{array}{l}\text { Refers to the degree that an organization stimulates the interaction between indi- } \\
\text { viduals and functionally distinct departments, promoting multidisciplinary activ- } \\
\text { ities that allow problem solving and innovation (Chen and Huang, 2007; Lee and } \\
\text { Grover, 2000; Liao et al., 2011;Tsai, 2002). }\end{array}$ \\
\hline $\begin{array}{l}\text { 5. Use of IT to facilitate the } \\
\text { process of storage and dis- } \\
\text { semination of information }\end{array}$ & $\begin{array}{l}\text { IT is a tool that facilitates and increases processes of knowledge storage and dis- } \\
\text { tribution (Lee et al., 2012; Lee and Grover, 2000; Ramezan, 2011). }\end{array}$ \\
\hline
\end{tabular}

Table 5 - Main initiatives and authors related to the organizational structure

ISSN: 07 I8-2724. (http://www.jotmi.org)

Journal of Technology Management \& Innovation (c) Universidad Alberto Hurtado, Facultad de Economía y Negocios. 
zation fails to develop their primary knowledge, their ability to access and incorporate new technologies to their routines becomes reduced (March, I99I; Volberda et al, 2010).

While organizations with higher level of absorptive capacity tend to be more dynamic (Teece, 2007; Volberda et al., 20l0), that is, are able to explore opportunities in the environment, regardless of the current performance; organizations with lower level of absorptive capacity tend to be more reactive, because they seek ways to correct their flaws, based on standards of performance that do not mean technological advancement (Anand et al., 20l0).

Exploration and exploitation represent two fundamentally different models for organizational learning. The first involves a company's behavior aimed at the research, discovery and experimentation, while the second is characterized by refinement, implementation, efficiency, production and selection (March, 1991; Volberda et al., 2010).The returns associated with the exploration are more variable and of longterm, while the returns related to exploitation are more precise and of short-term. In other words, companies that explore new knowledge produce a wide range of performance, while the use of exploitation leads to a more stable performance (March, 1991).
There is a complementary effect between the two strategies: the exploitation promotes static optimization, and exploration supports dynamic optimization (March, 1991). The success of a company to compete in stable environments involves the exploitation of consolidated skills, while to survive in dynamic environments involves the development of new skills. Thus, the two strategies are essential to maintain a competitive advantage and their combination is implied in recent concepts that address the dynamic capabilities of an organization (Eisenhardt; Martin, 2000). Table 6 presents the organizational initiatives related to the development and absorption of knowledge, extracted from seven papers on the subject.

\section{Implications of organizational constructs on the KM process}

The two previous sections performed a theoretical survey on the KM process and on the organizational constructs that sustains it. This section aims to raise the implications of organizational constructs on the KM process, answering the second research question: How each of these constructs relates to the stages of the KM process (acquisition, storage, distribution and knowledge utilization)? In order to achieve this goal, this section conducts a relationship for each construct with the four phases of the KM process (Knowledge acquisition, storage, distribution and utilization). Tables 7-10 summarize the existing relationship between the four phases of KM process and the five mapped organizational constructs.

\begin{tabular}{|c|c|}
\hline Initiatives & Definition \\
\hline $\begin{array}{l}\text { 1. Ability to absorb new } \\
\text { knowledge }\end{array}$ & $\begin{array}{l}\text { Refers to the ability of an organization to assimilate and apply a knowledge } \\
\text { for competitive advantage (Anand et al., 2010; Cohen and Levinthal, 1990; } \\
\text { March, 1991; Volberda et al., 2010) }\end{array}$ \\
\hline $\begin{array}{l}\text { 2. Exploitation and ex- } \\
\text { ploration of knowledge }\end{array}$ & $\begin{array}{l}\text { Refers to the knowledge utilization acquired. The exploitation refers to the use } \\
\text { of the same knowledge base, while exploration involves research and discov- } \\
\text { ery of new knowledge, generating innovation (Cohen and Levinthal, 1990; } \\
\text { Holmqvist, 2004; March, 1991; Volberda et al., 2010). }\end{array}$ \\
\hline $\begin{array}{l}\text { 3. Primary knowledge } \\
\text { utilization in order to } \\
\text { increase competitiveness }\end{array}$ & $\begin{array}{l}\text { The organization stores in its organizational memory a knowledge base that } \\
\text { facilitates the acquisition of new knowledge (March, 1991; Volberda et al., } \\
\text { 2010). }\end{array}$ \\
\hline $\begin{array}{l}\text { 4. Access to new technol- } \\
\text { ogies }\end{array}$ & $\begin{array}{l}\text { Partnerships, alliances and associations with other companies and universities } \\
\text { are sources of generation of new knowledge (Anand et al., 2010; Eisenhardt } \\
\text { and Martin, 2000; Teece, 2007). }\end{array}$ \\
\hline 5. Dynamic capability & $\begin{array}{l}\text { Refers to the ability of the organization to rebuild its core competencies, re- } \\
\text { maining competitive (Anand et al., 2010; Teece } \text { et al., 1997; Teece, 2007; Zol- } \\
\text { lo and Winter, 2002). }\end{array}$ \\
\hline
\end{tabular}

Table 6 - Main initiatives and authors related to the development and absorption of knowledge

ISSN: 07 I8-2724. (http://www.jotmi.org) 


\begin{tabular}{|c|c|c|c|c|}
\hline $\begin{array}{l}\text { Human Resources } \\
\text { Development }\end{array}$ & Team work & Organizational culture & $\begin{array}{l}\text { Organizational } \\
\text { structure }\end{array}$ & $\begin{array}{l}\text { Development and absorp- } \\
\text { tion of knowledge }\end{array}$ \\
\hline $\begin{array}{l}\text { Knowledge creation } \\
\text { depends on the accu- } \\
\text { mulation of skills of } \\
\text { persons (Chen and } \\
\text { Huang, 2009; Lee } \\
\text { and Yang, 2000) and } \\
\text { training programs } \\
\text { are important mecha- } \\
\text { nisms for knowledge } \\
\text { acquisition (Vlachos, } \\
\text { 2008). The cognitive } \\
\text { ability of individuals } \\
\text { stimulates the creative } \\
\text { process (Sparkes } \\
\text { and Miyake, 2000). } \\
\text { Award systems should } \\
\text { strengthen an attitude } \\
\text { of risk-taking (Laurs- } \\
\text { en and Foss, 2003). }\end{array}$ & $\begin{array}{l}\text { The creation of } \\
\text { knowledge depends } \\
\text { on a work context } \\
\text { in which there is } \\
\text { communication, } \\
\text { collaboration and } \\
\text { connection between } \\
\text { individuals (Huang, } \\
\text { 2009; Lee, 2013; } \\
\text { Liebowitz et al., } \\
\text { 2007). All knowl- } \\
\text { edge is originated } \\
\text { from the thought } \\
\text { that surrounds a } \\
\text { group (Brown and } \\
\text { Duguid, 2001). }\end{array}$ & $\begin{array}{l}\text { An organizational } \\
\text { environment that en- } \\
\text { courages experimen- } \\
\text { tation and learning } \\
\text { promotes the creation } \\
\text { of new knowledge } \\
\text { (Gold et al., 2001). } \\
\text { The knowledge-ori- } \\
\text { ented culture encour- } \\
\text { ages the employee } \\
\text { to propose ideas and } \\
\text { develop trial and error } \\
\text { activities (Cardoso, et } \\
\text { al., 2012; Skerlavaj et } \\
\text { al., 2007). }\end{array}$ & $\begin{array}{l}\text { More rigid hierar- } \\
\text { chical structures } \\
\text { reduce the deci- } \\
\text { sion-making and, as } \\
\text { a result, the process } \\
\text { of learning (An- } \\
\text { drews and Kacmar, } \\
\text { 2001). The creative } \\
\text { process is extremely } \\
\text { influenced by com- } \\
\text { munication between } \\
\text { the various areas of } \\
\text { the company (Chen } \\
\text { and Huang, 2010; } \\
\text { Lee et al., 2012). }\end{array}$ & $\begin{array}{l}\text { Organizational learning } \\
\text { enables the development } \\
\text { of new skills (Crossan et } \\
\text { al., 1999). The creation of } \\
\text { knowledge depends on the } \\
\text { common knowledge base } \\
\text { developed by individuals } \\
\text { (Cohen and Levinthal, } \\
\text { 1990; Holmqvst, 2004). } \\
\text { The common knowledge } \\
\text { base of the organization } \\
\text { promotes the reconstruction } \\
\text { of core competencies of the } \\
\text { organization, that is, those } \\
\text { related to the dynamic ca- } \\
\text { pacity of the organization } \\
\text { (Zollo and Winter, 2002; } \\
\text { Teece } \text { et al., 1997; Teece, } \\
\text { 2007). }\end{array}$ \\
\hline
\end{tabular}

Table 7 - Implications of organizational constructs on the knowledge acquisition process

\begin{tabular}{|c|c|c|c|c|}
\hline $\begin{array}{l}\text { Human Resources } \\
\text { Development }\end{array}$ & Team work & Organizational culture & $\begin{array}{l}\text { Organizational } \\
\text { structure }\end{array}$ & $\begin{array}{l}\text { Development and absorp- } \\
\text { tion of knowledge }\end{array}$ \\
\hline $\begin{array}{l}\text { Employees are an } \\
\text { important part of the } \\
\text { organization's knowl- } \\
\text { edge assets. Individ- } \\
\text { uals are responsible } \\
\text { for the storage of tacit } \\
\text { knowledge, retained } \\
\text { in the form of experi- } \\
\text { ence and skill (Walsh } \\
\text { and Ungson, 1991). } \\
\text { The organization must } \\
\text { create mechanisms for } \\
\text { performance measure- } \\
\text { ment and awards that } \\
\text { include the explana- } \\
\text { tion of knowledge in } \\
\text { order to institution- } \\
\text { alize it (Collins and } \\
\text { Clark, 2003). }\end{array}$ & $\begin{array}{l}\text { The members of a } \\
\text { group store knowl- } \\
\text { edge and common } \\
\text { language, as well as } \\
\text { the decision-mak- } \\
\text { ing mechanisms } \\
\text { and relationship } \\
\text { specific to the team } \\
\text { (Brown and Du- } \\
\text { guid, 2001). }\end{array}$ & $\begin{array}{l}\text { The retention of } \\
\text { knowledge requires } \\
\text { from the organization } \\
\text { discipline in identify- } \\
\text { ing new knowledge } \\
\text { and encoding them } \\
\text { when possible (Alavi } \\
\text { and Leidner, 2001; De- } \\
\text { long and Fahey, 2000), } \\
\text { as well as keeping the } \\
\text { human capital in order } \\
\text { to maintain the tacit } \\
\text { knowledge and know- } \\
\text { how acquired over } \\
\text { time (Rowley, 2001). }\end{array}$ & $\begin{array}{l}\text { Storage of explicit } \\
\text { knowledge through } \\
\text { procedures, manu- } \\
\text { als and instructions } \\
\text { is inherent to the } \\
\text { formal structure of } \\
\text { the organization } \\
\text { (Andrews and Kac- } \\
\text { mar, 2001; Liao et } \\
\text { al., 2011). IT is a } \\
\text { tool that can help } \\
\text { in the process of } \\
\text { knowledge storage } \\
\text { (Ramezan, 2011; } \\
\text { Leidner and Elam, } \\
\text { 1995). }\end{array}$ & $\begin{array}{l}\text { The knowledge stored by } \\
\text { the organization is the basis } \\
\text { for the exploitation of op- } \\
\text { portunities (Volberda } \text { et al., } \\
\text { 2010). The accumulation } \\
\text { of knowledge over a period } \\
\text { of time makes it easy the } \\
\text { acquisition in later periods } \\
\text { (Cohen and Levinthal, } \\
\text { 1990). }\end{array}$ \\
\hline
\end{tabular}

Table 8 - Implications of organizational constructs on the knowledge storage process

ISSN: 07I 8-2724. (http://www.jotmi.org)

Journal of Technology Management \& Innovation (c) Universidad Alberto Hurtado, Facultad de Economía y Negocios. 


\begin{tabular}{|c|c|c|c|c|}
\hline $\begin{array}{l}\text { Human Resources } \\
\text { Development }\end{array}$ & Team work & Organizational culture & $\begin{array}{l}\text { Organizational struc- } \\
\text { ture }\end{array}$ & $\begin{array}{l}\text { Development and ab- } \\
\text { sorption }\end{array}$ \\
\hline $\begin{array}{l}\text { The development of } \\
\text { skills enables the indi- } \\
\text { vidual to absorb new } \\
\text { knowledge (Zangiski } \\
\text { et al., 2013; Pandey } \\
\text { and Duta, 2013). This } \\
\text { way, the motivation } \\
\text { and the skill level of } \\
\text { individuals support or } \\
\text { restrict the process of } \\
\text { distribution of knowl- } \\
\text { edge (Rowley, 2001). } \\
\text { The group-based } \\
\text { incentives reinforce } \\
\text { cooperation, encour- } \\
\text { aging the dissemina- } \\
\text { tion and integration } \\
\text { of knowledge (Leon- } \\
\text { ard-Barton, 1992; } \\
\text { Vlachos, 2008). }\end{array}$ & $\begin{array}{l}\text { Work teams share } \\
\text { goals and language, } \\
\text { favoring the exchange } \\
\text { of knowledge (Brown } \\
\text { and Duguid, 2001). } \\
\text { Much of the knowl- } \\
\text { edge is not converted } \\
\text { to the explicit state } \\
\text { and, thus, its spread is } \\
\text { given by group work } \\
\text { (Schuring, 1996; } \\
\text { London and Sessa, } \\
\text { 2007). }\end{array}$ & $\begin{array}{l}\text { The culture of knowl- } \\
\text { edge must promote } \\
\text { the dissemination of } \\
\text { knowledge (Davenport } \\
\text { and Prusak, 1998), as } \\
\text { well as a sense of trust } \\
\text { between individuals } \\
\text { (Delong and Fahey, } \\
\text { 2000). The identifica- } \\
\text { tion with the company } \\
\text { is required so that the } \\
\text { employee can feel moti- } \\
\text { vated to share the ac- } \\
\text { quired knowledge (Fey } \\
\text { and Denison, 2003; } \\
\text { Irani et al., 2009). }\end{array}$ & $\begin{array}{l}\text { Organizations should } \\
\text { intensify the flow of } \\
\text { knowledge and create } \\
\text { sharing environments } \\
\text { (Chen and Huang, } \\
\text { 2007; Lee and Gro- } \\
\text { ver, 2000) and IT } \\
\text { facilitates this process } \\
\text { of dissemination (Lee } \\
\text { and Grover, 2000). } \\
\text { Organizational barri- } \\
\text { ers, created between } \\
\text { departments, prevent } \\
\text { the dissemination } \\
\text { of knowledge (Tsai, } \\
\text { 2002). Horizontal } \\
\text { structures promote } \\
\text { the flow of knowl- } \\
\text { edge (Tsai, 2002). }\end{array}$ & $\begin{array}{l}\text { The process of distri- } \\
\text { bution of knowledge } \\
\text { depends on the learning } \\
\text { ability of individuals } \\
\text { (Rowley, 2001), and } \\
\text { the capacity to ab- } \\
\text { sorb and assimilate } \\
\text { knowledge, internally } \\
\text { or externally to the } \\
\text { organization, requires } \\
\text { a common knowledge } \\
\text { base by the individuals } \\
\text { (March, 1991; Eisen- } \\
\text { hardt; Martin, 2000). } \\
\text { The distribution of } \\
\text { knowledge is a process } \\
\text { of interpretation and in- } \\
\text { tegration of knowledge, } \\
\text { that is, development } \\
\text { of a common language } \\
\text { and shared understand- } \\
\text { ing (Crossan et al., } \\
\text { 1999). }\end{array}$ \\
\hline
\end{tabular}

Table 9 - Implications of organizational constructs on the knowledge distribution process

\begin{tabular}{|c|c|c|c|c|}
\hline $\begin{array}{c}\text { Human Resources } \\
\text { Development }\end{array}$ & Team work & Organizational culture & $\begin{array}{l}\text { Organizational struc- } \\
\text { ture }\end{array}$ & $\begin{array}{l}\text { Development and ab- } \\
\text { sorption of knowledge }\end{array}$ \\
\hline $\begin{array}{l}\text { Competence refers } \\
\text { to the ability of in- } \\
\text { dividuals to use the } \\
\text { acquired knowledge } \\
\text { in practical situations } \\
\text { in order to solve } \\
\text { problems (Zarifian, } \\
\text { 2001). Systems for } \\
\text { performance man- } \\
\text { agement and rewards } \\
\text { should reinforce a } \\
\text { proactive attitude of } \\
\text { employees, aiming } \\
\text { at problem solving } \\
\text { and continuous im- } \\
\text { provement (Chen and } \\
\text { Huang, 2009). }\end{array}$ & $\begin{array}{l}\text { The individuals of } \\
\text { a group share goals } \\
\text { and are encouraged } \\
\text { to develop prob- } \\
\text { lem-solving activity } \\
\text { in order to achieve the } \\
\text { goals proposed to the } \\
\text { group (Liebowitz et } \\
\text { al., 2007; Schuring, } \\
\text { 1996). The group has } \\
\text { multifunctional char- } \\
\text { acteristics due to the } \\
\text { complementary skills } \\
\text { of the individuals that } \\
\text { compose it, facili- } \\
\text { tating the process of } \\
\text { problem solving (Lon- } \\
\text { don and Sessa, 2007). }\end{array}$ & $\begin{array}{l}\text { The knowledge culture } \\
\text { assumes that there is a } \\
\text { virtuous cycle of dis- } \\
\text { semination and subse- } \\
\text { quent knowledge utili- } \\
\text { zation (Skerlavaj et al., } \\
\text { 2007). The culture of } \\
\text { knowledge emphasizes } \\
\text { the constant reflection } \\
\text { on the actions taken } \\
\text { (Irani } \text { et al., 2009). }\end{array}$ & $\begin{array}{l}\text { Knowledge utiliza- } \\
\text { tion can occur auto- } \\
\text { matically, reflecting } \\
\text { a recovery process } \\
\text { through an organiza- } \\
\text { tional routine (Walsh } \\
\text { and Ungson, 1991). } \\
\text { The use also occurs } \\
\text { through the rescue } \\
\text { of explicit knowl- } \\
\text { edge, encoded in an } \\
\text { information system } \\
\text { (Leidner and Elam, } \\
\text { 1995; Ramezan, } \\
\text { 2011). Less vertical } \\
\text { hierarchical struc- } \\
\text { tures decentralize } \\
\text { decision-making and, } \\
\text { consequently, the use } \\
\text { of knowledge (An- } \\
\text { drews and Kacmar, } \\
\text { 2001; Liao et al., } \\
\text { 2011). }\end{array}$ & $\begin{array}{l}\text { Knowledge must be } \\
\text { used as the basis for } \\
\text { the creation of new } \\
\text { knowledge (Teece et } \\
\text { al., 1997). The use } \\
\text { assumes an exploiting } \\
\text { role, i.e. decision-mak- } \\
\text { ing using the same } \\
\text { knowledge base, or } \\
\text { an exploratory one, } \\
\text { when the knowledge } \\
\text { base is used as a com- } \\
\text { mon knowledge to } \\
\text { create new knowledge } \\
\text { (March, 1991). The use } \\
\text { of acquired knowledge } \\
\text { is associated with the } \\
\text { dynamic capability of } \\
\text { an organization (Teece } \\
\text { et al., 1997; Teece, } \\
\text { 2007; Zollo and Win- } \\
\text { ter, 2002). }\end{array}$ \\
\hline
\end{tabular}

Table 10 - Implications of organizational constructs on the knowledge utilization process

ISSN: 07 I 8-2724. (http://www.jotmi.org)

Journal of Technology Management \& Innovation (c) Universidad Alberto Hurtado, Facultad de Economía y Negocios. 
Considering that knowledge depends on action, and the human is the organizational agent able to mobilize efforts, the development of $\mathrm{HRs}$ can be considered the organizational construct that is the base of the KM process. A skilled employee is able to assimilate knowledge that is internal and external to the organization, developing a common knowledge base, which enables the exploration and exploitation of knowledge in innovation and improvement activities, facilitating and intensifying the dissemination of knowledge, such as best organizational practices (Rowley, 200I).

Teamwork is the construct that promotes the interaction of individuals. Through interaction, it becomes possible to transfer knowledge, in particular, the tacit portion (Okhuysen; Eisenhardt, 2002). The groups develop, over time, a common identity, sharing language and culture, making them cohesive (Brown; Duguid, 200I). This state of cohesion and common identity, along with the characteristics of complementary conceptual, management and human skills present in groups, facilitate interaction and exchange of knowledge, as well as the development of activities aiming at problem solving and improvement (Lee et al., 20I3; Huang, 2009).

Organizational culture carries with it assumptions and values considered acceptable and correct by a group of individuals, directing the way of acting of individuals (Skerlavaj et al., 2007). The KM depends on persons who are engaged in sharing and integrating knowledge (Fey and Denison, 2003), allowing its transformation.

The organizational structure is related to the degree of centralization, formalization and integration (Chen et al., 2010; Chen; Huang, 2007). Thus, the organizational structure interferes with the decision-making process, which interferes with learning and mobilization of individuals (Andrews; Kacmar, 200I; Damanpour, 199I), the routine maintenance through procedures, instructions and manuals (Chen; Huang, 2007), and the flow and integration of knowledge among distinct employees and departments (Liao et al., 20 I I).

The absorption capacity and knowledge development address the ability of individuals to develop and retain a common knowledge base, which promotes learning. The learning process can mean the exploitation, related to the use the same knowledge base, or exploration of knowledge, which deals with the research and discovery of new knowledge, generating innovation (March, 1991). This exploratory and exploiting learning ability dictates the level that the organization has to rebuild its skills, that is, its dynamic ability (Zollo; Winter, 2002; Teece et al. 1997). Tables 7 to 10 summarize the existing relationships between the four stages of the KM process (acquisition, storage, distribution and use of knowledge) and the five organizational constructs mapped.

\section{Conclusions}

This study points to the fact that KM is much more complex than the management of information and adoption of tools focused on IT, in turn, must be understood as support mechanisms for KM. The theoretical study performs a mapping of four phases of the KM process. From the characteristics of the KM process five organizational aspects, called organizational constructs that support the KM process are identified: human resource development, teamwork, organizational culture, organizational structure and knowledge development and absorption.

The human resource development is the basis for the KM process, because, since knowledge is related to the practical activity and manifests itself through the individual, the development of competences and skills becomes critical to the creation of a common knowledge base.

Teamwork is an important organizational aspect in order to create people with common language and identity, encouraging the dissemination of knowledge. In the work are formed problem solving and incremental improvements teams that enable the processes of knowledge acquisition and utilization, stimulating exploitative and explorative learning, responsible for the transformation of knowledge. In addition, teamwork is responsible for the distribution of knowledge, since employees of different skill and experience level are put together, and also allows employees make contact with multidisciplinary knowledge, considering that groups are formed of individuals by different areas of expertise.

Organizational culture primarily functions as a repository of knowledge, as it determines how individuals act and behave. The knowledge-oriented culture stimulates the continuous dissemination of knowledge between individuals and also favors the development of improvements and innovations related to the exploitation and exploration of knowledge.

The fourth construct é called organizational structure, relates mainly to the integration of employees and functions of the organization. Structures that enable the flow of knowledge and horizontal interaction between individuals encourage interdisciplinary activities. The structure also refers to the level of autonomy that employees have for making decisions impacting the learning process, and formalization, which refers to the storage of explicit knowledge. More formalized and hierarchical structures tend to inhibit the creative process, because they are focused on repetition. Lean structures are more receptive to the acquisition and dissemination of knowledge.

Finally, development and absorption of knowledge is the construct related to the ability of individuals in building a 
common knowledge base, which favors the integration of new knowledge, internally and externally to the organization, and also to the dynamic capability, i.e., the ability of the organization to rebuild its skills, becoming innovative (Teece et al., 1997; Zollo; Winter, 2002).

Thus, this article points out that the KM process requires from the organization the development of characteristics that go beyond the use of information technology. IT becomes important as a mechanism of support to the process of knowledge storage and distribution and organizational constructs become fundamental for the development of an organization effectively focused on knowledge.

\section{I Implications for managers}

It consolidated the concept of the importance of knowledge for organizational competitive advantage. Moreover, many publications address the need of organizations to treat knowledge as an organizational asset of the first order, being necessary to manage this asset. However, a question that may arise on the part of organizational managers in understanding which is related to the internal organization contextual factors must be developed in order to support KM. This article contributes to the company managers defining a theoretical framework that deals with the phases that make up the KM process (knowledge acquisition, storage, distribution and use), and also identifies a group of five constructs or organizational factors that should be considered by managers in order to support this process. Without managerial commitment to develop appropriate organizational characteristics, any initiatives to $K M$ return evasive results. Thus, this paper focuses its contribution around five constructs related to organizational KM: human resource development, teamwork, organizational culture, organizational structure and knowledge development and absorption. For each construct considerations on initiatives that support the KM are performed, moreover, the paper also discusses the implications of these constructs on the four phases of the KM process.

\subsection{Limitations of the study and future research di- rections}

This paper develops a theoretical mapping of the factors that impact the KM process. From a theoretical framework about the KM, constructs from the organizational development viewpoint that support this process are identified. A limitation of this study relates to the selection of constructs. This work focuses on a contribution related to the internal context characteristics, however, does not consider environment aspects, e.g., the size of the organization, the industry that the organization operates and sectoral technological characteristics. Thus, a proposal for future work is to theo- retically evaluate the exogenous aspects of the organization that relates to $\mathrm{KM}$ process.

Since this is a theoretical study, another limitation also refers to the empirical validation of these constructs, and the relative importance of each construct across the KM process. Thus, future work can search empirically these two issues.

\section{References}

ALAVI, M., Leidner, D.E. (200I). Knowledge Management and Knowledge Management Systems: conceptual Foundations and Research Issues. MIS Quarterly, 25(I), 107-I36. doi: |0.2307/325096|

ALVESSON, M., Kärreman, D. (200I). Odd couple: Making sense of the curious concept of knowledge management. Journal of Management Studies, 38(7), 995-I018. doi: | 0. I I | |/ |467-6486.00269

ANAND, J., Oriani, R.,Vassolo, R.S. (2010).Alliance activity as a dynamics capability in the face of a discontinuous technological change. Organization Science, 21 (6), 1213-1232. doi: 10.1287/1090.0502

ANDREWS, M.C., Kacmar, K.M. (200I). Discriminating among organizational politics, justice, and support. Journal of Organization Behavior, 22(4), 347-66. doi: |0.| | 08/004834807|077398|

BHATT, G.D. (2002). Management strategies for individual knowledge and organizational knowledge. Journal of Knowledge Management, 6(I), 3I-39.

BROWN, J.S., Duguid, P. (200I). Knowledge and Organization: A social-practice perspective. Organization Science, 12(2), 198-2 I3. doi: 10.1287/orsc. 12.2.198.10116

CARDOSO, L., Meireles, A., Peralta, C.F. (20I2). Knowledge management and its critical factors in social economy organizations. Journal of knowledge management, 16(2), 267-284. doi: |0.| |08/|367327|2| |2|886|

CHEN, C.J., Huang, J.W. (2007). How organizational climate and structure affect knowledge management: the social interaction perspective. International Journal of Information Management, 27(2), I04-I8. doi: I0.10 I6/j.ijinfomgt.2006. I I.00 I

CHEN, C.J.and Huang, J.W. (2009). Strategic human resource practices and innovation performance: The mediating role of knowledge management capacity. Journal of Business Research, 62, 104-II4. http://dx.doi.org//0.1016/j.jbusres.2007.11.016 
CHEN, C.J, Huang, J.W., Hsiao, Y.C. (20I0). Knowledge management and innovativeness: The role of organizational climate and structure. International Journal of Manpower, 3। (8), 848-870. doi: I0.I I08/0 I 43772 I0I I088548

COHEN, W.M., Levinthal, D.A. (1990). Absorptive Capacity: A new perspective on learning and innovation. Administrative Science Quarterly, 35, 128-152. doi: I0.1 177//350507608096037

COLLINS, C.J., Clark, D.C. (2003). Strategic human resource practices, top management team networks, and firm performance:The role of human resource practices in creating organizational competitive advantage. The Academy of Management Journal, 46(6), 740-75I. doi: 10.2307/30040665

CORMICAN, K., O'Sullivan, D.A. (2003). Collaborative knowledge management tool for product innovation management. International Journal of Technology Management. 26(I), 53-68. doi: I0.1504/..003|44

CROSS, R., Sproull, L. (2004). More than an answer: Information relationships for actionable knowledge. Organization Science, I5(4), 446-462. doi: 10.1287/orsc. 1040.0075

CROSSAN, M., Lane, H.W., White, R.E. (1999). An organizational learning framework: From intuition to institution. Academy of Management Review, 24(3), 522-537. doi:10.5465/AMR.1999.2202135

CUMMINGS, J.N. (2004). Work groups, structural diversity, and knowledge sharing in a global organization. Management Science, 50(3), 352-264. doi: 10.1287/mnsc. I030.0134

DAMANPOUR, F. (199I). Organizational Innovation: a metaanalysis of effects of determinants and moderators.Academy of Management Journal, 34(3), 555-590. doi: 10.2307/256406

DAVENPORT,T.H., De Long, D.W., Beers, M.C. (1998). Successful knowledge management projects. Sloan Management Review, 43-57.

DAVENPORT, T.H., Prusak, L. (1998). Working Knowledge: How organizations manage that they know, Harvard Business School Press, Boston, MA.

DELONG, D.W., Fahey, L. (2000). Diagnosing cultural barriers to knowledge management. Academy of Management Executive, I4(4), I I3- I27. doi: I0.5465/AME.2000.3979820

EISENHARDT, K.M., Martin, J.A. (2000). Dynamic capabilities: What are they? Strategic Management Journal. 2 I (I0), I I05II2I. doi: 10.1002/1097-0266
FARAJ, S., Sirkka, L.J., Majchrzak, A. (20I I). Knowledge Collaboration in online communities. Organization Science, 22(5), | 224-|239. doi: org//0.1287/orsc. I 100.06/4

FEY, C.E., Denison, D.R. (2003). Organizational culture and effectiveness: can American theory be applied in Russia? Organization Science, I4(6), 686-706. http://dx.doi.org//0.1287/ orsc. | 14.6.686.24868

GERMAIN, R. (1996). The role of context and structure in radical and incremental logistics innovation adoption. Journal of Business Research, 35, I17-127. http://dx.doi. org/I0.10I6/0I48-2963(95)00053-4

GOLD, A.H., Malhotra, A., Segars, A.H. (200I). Knowledge management: an organizational capabilities perspective. Journal of Management Information Systems, I8(I), 184-214. doi: 10.1287/mnsc.33.4.525

GONZALEZ, R.V.D., Martins, M.F. (20I4). Mapping the organizational factors that support knowledge management in the Brazilian automotive industry. Journal of Knowledge Management, 18(I), 152-I76, doi: I0.1108/JKM-08-20I30300.

GRANT, R.M. (1996). Toward a knowledge-based theory of the firm. Strategic Management Journal, 17, 109-122. doi: $10.2307 / 2486994$

HOLMQVIST, M. (2004). Experiential learning processes of exploration and exploitation within and between organizations:An empirical study of product development. Organization Science, I5(I), 70-8I. doi: 10. I287/orsc. 1030.0056

HUANG, C.C. (2009). Knowledge sharing, group cohesiveness on performance:An empirical study of technology R\&D teams in Taiwan. Technovation, 29, 786-797. http://dx.doi. org/I0.1016/j.technovation.2009.04.003

IRANI, Z., Sharif, A.M., Love, P.E.D. (2009). Mapping knowledge management and organizational learning in support of organizational memory. International Journal of Production Economics,122, 200-2/5. http://dx.doi.org//0.1016/j. ijpe.2009.05.020

JIMÉNEZ-JIMÉNEZ, D., Sanz-Valle, R. (2007). Managing human resource in order to promote knowledge management and technical innovation. Management Research, 5(2), 83100. doi: 10.2753/JMR I536-5433050202

KANE, G.C., Alavi, M. (2007). Information technology and organizational learning: An investigation of exploration and explotation process. Organization Science, 18(5), 796-812. http://dx.doi.org//0.1287/orsc. 1070.0286 
LAURSEN, K., Foss, N.J. (2003). New human resource management practices, complementarities, and the impact on innovation performance. Cambridge Journal of Economics, 27(2), 243-263. doi: 10.1093/cje/27.2.243

LEE, C.C., Grover, V. (2000). Exploring mediation between environment and structural attributes: the penetration of communication technologies in manufacturing organizations. Journal of Management Information System, 16(3), 187-217.

LEE, C., Yang, J. (2000). Knowledge value chain. The Journal of Management Development, 19(9), 783-794. doi: 10.1108/02621710010378228

LEE, J.H., Kim, Y.G. (200I). A stage model of organizational knowledge management: A latent content analysis. Expert System with Applications, 20(3), 299-3II. doi: 10.1177/0165551506076395

LEE, P.K.C., To, W.M., Ty, B. T.W. (20I3). Team attributes and performance of operational service teams: An empirical taxonomy development. International Journal of Production Economics, 142, 5I-60. http://dx.doi.org//0.1016/j. ijpe.2012.05.005

LEE, S., Kim, B.G., Kim, H. (20I2). An integrated view of knowledge management for performance. Journal of Knowledge Management, 16(2), 183-203. doi: 10.1108/1367327/21 I2/8807

LEIDNER, D.E., Elam, J.J. (1995). The impact of executive information systems on organization design, intelligence, and decision making. Organization Science, 6 (6), 645-664. doi: http://dx.doi.org// 0.1287/orsc.6.6.645

LEONARD-BARTON, D. (1998). Wellspring of knowledge, Harvard Business School Press, Boston, MA.

LIAO, C., Chuang, S.H., To, P.L. (20I I). How knowledge management mediates relationship between environment and organizational structure. Journal of Business Research, 64, 728-736. http://dx.doi.org/10.1016/j.jbusres.2010.08.00 I

LIEBOWITZ, J., Ayyavoo, N., Nguyen, H., Carran, D., Simien, J. (2007). Cross generational knowledge flows in edge organizations. Industrial Management \& Data Systems, 107(8), I |23-I |53. doi: I0.| I08/026355707/0822787

LIN, H.F.A. (2007).A stage model of knowledge management: an empirical investigation of process and effectiveness. Journal of Information Science, 33(6), 643-659. doi: 10.1177/0165551506076395
LONDON, M., Sessa,V.I. (2007). How groups learn, continuously. Human Resource Management, 46(4), 65I-669. doi: I0.1002/hrm.20186

LÓPEZ, S.P., Peón, J.M.M., Ordás, C.J.V. (2006). Managing Knowledge: The link between culture and organizational learning. Journal of Knowledge Management, 8(6), 93-104. doi: I0.1 I08/I36732704/0567657

LYTRAS, M., Pouloudi,A. (2006). Towards the development of a novel taxonomy of knowledge management systems from a learning perspective: an integrated approach to learning and knowledge infrastructures. Journal of Knowledge Management, I0(6), 64-80. doi: 10.1 I08/136732706/0709224

MARCH, J.G. (1991). Exploration and exploitation in organizational learning. Organization Science, 20(I), 7I-87. doi: http://dx.doi.org/I0.1287/orsc.2.I.7 I

MORGAN, G. (1996). Imagens da Organização, Editora Atlas, São Paulo.

NELSON, R., Winter, S. (1982). An evolutionary theory of economic change, Belknap Press/Harvard University Press, Cambridge.

OKHUYSEN, G.A., Eisenhardt, K.M. (2002). Integrating knowledge in groups: How formal interventions enable flexibility. Organization Science, I3(4), 370-386. doi: http://dx.doi. org/I0.1287/orsc. I3.4.370.2947

ORLIKOWSKI, W.J. (2002). Knowing in practice: Enacting a collective capability in distributed organizing. Organization Science, I3(3), 249-273. doi: http://dx.doi.org//0.1287/ orsc. 13.3.249.2776

PANDEY, S.C., Duta, A. (2013). Role of knowledge infrastructure capabilities in knowledge management. Journal of knowledge management, 17(3), 435-453. doi: 10.1108/JKMII-2012-0365

POYNDER, R. (1998). Getting to the nuts and bolts of knowledge management. Information World Review, I35(I35), 20.

QUIGLEY, N.R., Tesluk, P.E., Locke, E.A., Bartol, K.M. (2007). A multilevel investigation of the motivational mechanisms underlying knowledge sharing and performance. Organization Science, 18(I), 7I-88. doi: http://dx.doi.org//0.1287/ orsc. 1060.0223

RAMEZAN, M. (20I I). Intellectual capital and organizational organic structure in knowledge society. International Journal of Information Management, 31, 88-95. doi: 10.1016/j.jijnfomgt.2010.10.004 
ROWLEY, J. (200I). Knowledge management in pursuit of learning. The learning with knowledge cycle. Journal of Information Science, 27(4), 227-237. doi: 10.1177/016555150102700406

SCHULTZE, U., Leidner, D. E. (2002). Studying knowledge management in information systems research: discourses and theoretical assumptions. MIS Quarterly, 26(3), 2I 3-242. doi: $|0.2307 / 4| 3233 \mid$

SCHURING, R.W. (1996). Operational autonomy explains the value of group work in both lean and reflective production. International Journal of Operations \& Production Management, I6(2), I7I-182. doi: 10.1 108/014435796/0197120

SKERLEVAJ, M., Stenberger, M.I., Skrinjar, R., Dimovski, V. (2007). Organizational learning culture: The missing link between business process change and organizational performance. International Journal of Production Economics, 106, 346-367. http://dx.doi.org/I0.1016/j.ijpe.2006.07.009

SPARKES, J.R., Miyake, M. (2000). Knowledge transfer and human resource development practices: Japanese firms in Brazil and Mexico. International Business Review, 9, 599-612. doi:I0.1016/S0969-593I(00)0002I-4

SWAN, J., Newell, S., Scarbrough, H., Hislop, D. (1999). Knowledge management and innovation: networks and networking. Journal of knowledge management, 3(4), 262-275. doi: I0.1 I08/I36732799/03040 I4

TEECE, D.J. (2007). Explicating dynamic capabilities: The nature and microfondations of (sustainable) entreprise performance. Strategic Management Journal, 28, I319-1350. doi: $10.1002 / \mathrm{smj} .640$

TEECE, D.J., Pisano, A., Shuen, A. (1997). Dynamic capabilities and strategic management. Strategic Management Journal, 18(7), 509-533. doi: 10.1002/(SICl) 1097-0266

TERZIOVSKI, M., Fitzpatric, P., O'Neill, P. (2003). Successful predictors of business process reengineering (BPR) in financial services. International Journal of Production Economics, 84(I), 35-50. http://dx.doi.org//0.1016/S09255273(02)00378-X

TSAI, W. (2002). Social structure of cooperation within a multiunit organization: Coordination, competition, and intraorganizational knowledge sharing. Organizations Science, |3(2), |79-190. doi: 10. I287/orsc. 13.2.179.536

VLACHOS, I.P. (2008). The effect of human resource practices on organizational performance: evidence from Greece. International Journal of Human Resource Management, 19(1), 74-97.doi: 10.1080/09585190701763933
VOLBERDA, H.W., Foss, N.J., Lyles, M.A. (20I0). Absorbing the concept of absorptive capacity: How to realize its potential in the organization field. Organization Science, $2 \mathrm{I}$ (4), 93 I-95 I. http://dx.doi.org// 0.1287/orsc. 1090.0503

WALSH, J. P., Ungson, G. R. (I99I). Organizational Memory. Academy of Management Review, I6(I), 57-9I. doi: 10.5465/ AMR.1991.4278992

WILKINSON, I., Young, L. (2006). On cooperating firms, relations and networks. Journal of Business Research, 55 (2), I23-132. http://dx.doi.org//0.1016/S0|48-2963(00)00|47-8

ZANGISKI, M.A.S.G., Lima, E.P., Costa, S.E.G. (20I3). Organizational competence building and development: Contributions to operations management. International Journal of Production Economics, 144, 76-89. http://dx.doi. org/10.1016/j.jpe.2013.01.02

ZARIFIAN, P. (200I). Objetivo competência: por uma nova lógica, Editora Atlas, São Paulo.

ZHENG, W., Yang, B., Mclean, G.B. (2010). Linking organizational culture, structure, strategy, and organizational effectiveness: Mediating role of knowledge management. Journal of Business Research, 63(7), 763-77I. http://dx.doi. org/10.1016/j.jbusres.2009.06.005

ZOLLO, M.,Winter, S.G. (2002). Deliberate learning and the evolution of dynamic capabilities. Organization Science, I3(3), 339-35I. http://dx.doi.org//0.1287/orsc. 13.3.339.2780 